Critical Studies in Improvisation / Études critiques en improvisation, Vol. 14, No. 1

\title{
A History of Violence
}

\section{Rinaldo Walcott}

I'm trying not to be angry. I'm trying not to despair. I'm really trying. I'm also failing.

When George Floyd was state-sanctioned lynched in Minneapolis, Minnesota in May 2020, something tremendous opened up. The global protests that followed on that act of police violence-witnessed by so many of us on our various media devices-caused an outpouring of protests like we had never seen before. In the initial days of the protests around North America and other parts of the world-and the uprising in Minneapolis-I searched newspapers for details of this most public police murder. In my search I found a few articles that also pointed out that Floyd had been exposed to COVID-19 too. The convergence of police violence and COVID19 on Floyd's body seem to encapsulate for me the tremendous suffering that Black people collectively inhabit in North America. In the midst of a pandemic and under stringent restrictions on movement and gathering in groups, George Floyd was murdered publicly for allegedly passing a counterfeit twenty-dollar bill. His murder by police tells a story of the kind of society in which we collectively reside.

Black people have long known that since the abolition of slavery, our lives are rendered cheap compared to others. No longer needed for our labour power on plantations and in trades or services in cities and towns, Black people and therefore Black life became expendable, so much waste to be discarded, abused, and rendered a hindrance to the nation and state. Seen from this perspective, the murder of George Floyd is not an accident; it is the extension of a logic and attitude toward Black people and Black life in which our very presence marks us as open for abuse, punishment, and death.

Floyd's death catalyzed something in many of you. For once, you seem to believe that what Black people say happens to us, what we must endure, is real. Sitting at home in the pandemic, attempting to save your life from a marauding virus allowed you some clear vision, if only for a few days, weeks, months. The image of George Floyd having his breath kneed out of him by a police officer should stay with us forever, and the image surely activated something in many of you. As Black people we have consistently repeated to you and for you that these things happen to us. I can only now believe that the reprieve the pandemic forced upon you allowed you to bear witness to the everyday quotidian violence that shapes Black people's lives. This banal violence that can end with our deaths has been disbelieved by you, often, even as we have spoken of it. You have persistently replied that we cannot be telling the truth. Our lives remain stubbornly other-worldly to you. However, in May 2020, for a brief moment we shared the same terrain, we witnessed the same act, we shared the same outrage, we desired a similar outcome: justice.

George Floyd could not breathe. He expired in front of us on our screens as state-sanctioned authority kneed the life out of him. We had seen this before. Eric Garner also could not breathe as state-sanctioned authority choked the breath out of him. We don't need to recount dates, times, months, years - these actions we have seen. You have seen. Black people bear witness to these acts daily. But what of those we do not see? Black people and Indigenous people have been trying to re-achieve our full breath in a post-Columbus Americas for almost five hundred years now. Therefore, it is somewhat ironic that one of the severe complications from COVID-19 infection is that it too takes one's breath away. The struggle to breathe, in some instances, is one of the deadly aspects of COVID-19 and from which intubation can follow; it too is a symptom that meets spectacular police violence in the streets, our homes, our schools, our 
workplaces. The convergence of the police violently stealing Black people's breath and COVID19 doing the same disproportionately among Black, Indigenous, and other non-white people across North America and the UK says something deeply profound and disturbing about the social and cultural arrangements of our time. Our lack of breath, Black breath, is not just about the impending catastrophe of climate change; our lack of breath has been baked into the structure of life in direct (dis)proportion to your ability to live full lives.

COVID-19 is a thief. I cannot tire of saying that the coronavirus has taken much from us collectively. It has stolen more than bodies. The stolen bodies have occupied some of us and so it should be. But COVID-19 has stolen sociality too. It has interrupted our very sense of being, of being together, of being in concert, of the presence of being. And because COVID-19 has severely interrupted our being together, the protests that followed Floyd's murder in the US, and then later the suspicious death of Regis Korchinski-Paquet in Toronto, demonstrated how Black life and death are a struggle for a more sustained and meaningful existence. And for a moment you were right there with us. You seem to share in that collective and common desire. People, in the middle of a pandemic, took to the streets to show their political disgust with statesanctioned violence, called out policing concerning both incidents, and demanded something that might look like justice.

Black and Indigenous life then is both wasted and needed. Wasted by white supremacist logics that seek to control a narrative of our non-existence or barely existence on the one hand; and on the other hand, another logic in which Black and Indigenous continued insistence on life, on lives lived beyond the reach of white supremacy, is coopted by the benevolent state as evidence that we are valued as people too. In Canada, the people took a knee in memory of George Floyd and even the politicians and police took knees too-the Prime Minister of Canada took a knee, the then Black police chief of Toronto took a knee. Taking a knee became a farce, a performance without substance. A distraction from the normal procedures that make Black and Indigenous life wasted, killable, not having to be accounted for by the state.

COVID-19 occupies and vacillates around the same white supremacist logics. We work in your factories, your warehouses, your delivery depots, your point-of-sale grocery shops, and therefore we remain open for infection. You claim we are all in this together, but we pay the cost with our lives. Your quick reaction policies have not apprehended the virus in our communities; our employment has not shifted to accommodate the deadly circulation of the virus. Our families, neighbours, and friends remain, in this moment of the pandemic, open to infection and available for police brutalities. The shock of George Floyd has receded; the image is no longer a motivating factor for you. You just want things to reopen. To get on with your life. The hard truth is that for some of us, things never were shut down. We remain open, open to abuse and so much unhumaning.

The killings have a long and unbroken history. The virus, I suspect, will have a long history among us too-by us I mean Black and Indigenous peoples. If HIV/AIDS is any indication, we see that white people in Canada experience an "endgame" for HIV infection and its devastation of life. However, in Canada, the US, and any place where large numbers of Black people live, HIV remains an epidemic. How or why is this the case? The logics that underwrite who is considered human continue to position Black and Indigenous people on its outer reaches. Once placed there, there is no coming back. We see that Black and Indigenous peoples have been given no priority for vaccination even though we are more severely impacted and do the labour to keep your economy open, as our politicians never tire of telling us. We see no change in policies like paid sick leave for our working poor families, neighbours, and friends. The ranks of essential workers are filled with non-white people, needed only to keep your precious economy 
pumping but not needed enough to be a priority for wellness, for life.

It took you six months and longer to provide rapid testing, isolation centers, and other mechanisms for interrupting the virus in low-income non-white communities, even though you knew we were more impacted by COVID-19. We have never been "all in this together." The claim obscures a history of violence, a history that is alive and functions to make some lives valuable and others not so. COVID-19 is a convergence. It converges with police violence and other state violences to render some lives less than life, less than worth living, less than worth saving. That we can inhabit a world where the disposability of some lives makes other lives more livable as the normal course of living is exemplary of the crisis in which modern life finds itself. The coming climate catastrophe is but one element of the degradation of planetary life. The impossible persistence of Black and Indigenous life is a profound critique-but more so a profound insistence-that we can collectively live better together-but we must want it to be so. We must collectively work to make it so. The COVID-19 pandemic has shown us the profound collective spirit of Black and Indigenous people. Now is the time for others to act.

Am I angry? Yes, I am. Am I in despair? Yes, I am. And yet I know Black and Indigenous peoples will do something more than survive all this. We will continue to live lives full of rich possibilities, even as we are surrounded by assault after assault.

And yes, this was written with you in mind. Yes, you who might be reading this right now. Yes, you have work to do. So, get to it. 